\title{
Existing in Time: John Updike”s “The Music School” (1966)
}

\author{
Goetz Egloff \\ Practice for Psychoanalysis, Mannheim, Germany
}

Email address:

goetz.egloff@alumni.uni-heidelberg.de,g.egloff.medpsych.ma@email.de

\section{To cite this article:}

Goetz Egloff. Existing in Time: John Updike's “The Music School” (1966). International Journal of Literature and Arts. Vol. 5, No. 5, 2017, pp. 46-51. doi: 10.11648/j.ijla.20170505.11

Received: June 28, 2017; Accepted: July 17, 2017; Published: August 11, 2017

\begin{abstract}
The essay addresses issues of existence and time in John Updike's short story, "The Music School", which was published in 1966 in a short story collection by the same name. While waiting for his daughter in a music school, the writer Alfred Schweigen reflects on the complexities of life, describing his thoughts and impressions. In his everyday dealings with reality, by way of contrasting materiality to immateriality he attempts to make sense of existence as it comes into view. Especially, time not so much as an objective category but as a matter of subjective experiencing is an important aspect. Time as a musical category of rhythm, and as rhythm of life and of transience, is a topos the narrator makes a draft on, approaching an existential view of real-world issues through life philosophy. Some others of Updike's stories of the sixties make for a thematic kinship, so that it becomes obvious that existence in reference to time provides a point of departure to gain insight into being.
\end{abstract}

Keywords: John Updike, “The Music School”, Short Story, Time, Existence, Literary Modernism

\section{John Updike and the Short Story}

"What American short-story writers have always offered is a vision of life that must transcend reportage with metaphor (...)." [1] "Die Short Story soll dem Leben aehnlich sein, das vielfach undurchschaubar ist und keine eindeutigen, endgueltigen Antworten kennt." [2] A basic topos of the American short story in the twentieth century can be traced to the specific American experiencing of life and reality which can be described as of a young people being in a strange country. In the early 'tall tales' a view of man had crystallized that would influence many stories of authors to come. [3] "Als 'amerikanischer Held' erschien der Mann, der mit gesundem Menschenverstand, Energie und Ausdauer sowie einer guten Portion Humor die mannigfachen Schwierigkeiten des Lebens zu meistern verstand (...)." [4] Yet, by gaining insight into the multi-layered complexities of life opposing the then-common optimism, a change of consciousness began influencing the contemporary short story, having continued until this day. After skepticism toward any superficial optimism and toward passed-on societal views, attitudes, and modes of behavior had been worded by the 'dark authors' of the nineteenth century, like Hawthorne, Melville, and Poe, now prominence would be given to psychological aspects. [5] With that, a dynamic plot would be eclipsed. Instead, it would be replaced by a rather static episode showing a cutout from everyday life and embracing the human experience of being in a multi-layered reality and of being oneself an unfledged character in search of something. [6] [7] [8]

John Updike's short story, "The Music School", from the 1966 short story collection that goes by the same name is an excellent example for that static episode narrative. The protagonist, Alfred Schweigen, tells about his observations and experiences. As often in Updike, the minimization of time spaces is the framework for the development of the story. "Aware that the stories in 'The Music School' may not appeal to readers who look for the obvious drama of development and climax (...)," [9] any of these have been abandoned due to suspicion of artificiality and in favor of a psychograph of the protagonist. Updike's most prominent topics, like exploring of the world of children and adolescents, or, depicting of the monotony of everyday life, and the critique of modern mass civilization find themselves on the micro level of couple relationship issues usually marked by mutual frustration, hostility, and lack of communication. [10] In "The Music School", the protagonist draws on these topics mostly in a reflecting way, or in a reminiscing fashion, skipping to and fro time. "Ideally, in 
modern short stories, each new paragraph should offer a succession of surprises or intensifying symbols; (...) the resulting fiction is closer in form to poetry than it is to traditional fiction." [11] This fits the story well, since the protagonist, Schweigen, almost hot-swaps between time levels, mediating his thoughts in an ambivalent way, yet in their complexity approaching some wholeness of gestalt. After all, in "(...) treating the madness of the self (...) the writer in recent American fiction describes psychological derangement from the inside." [12] This motif of inner distraction is pivotal not only in "The Music School" but also in other works of Updike's: "He inherits, and richly extends, the modernist project of sexual candor and psychological investigation (...)." [13] Modernism in the sixties has distinctively been helped take shape by Updike. [14] Moreover, Ahrends precises that among contemporary authors stylistically Updike inhabits an exceptional position, and structurally he is the outstanding representative of the conventional "well-made story (...)." [15]

\section{2. "The Music School"}

The writer Alfred Schweigen, while waiting for his daughter in a music school, describes thoughts and impressions that move and afflict him. He tells about a young priest who told him about a change of attitude toward the wafer of the Eucharist in his church the night before. After it had been rated blasphemous for generations, chewing of the wafer will officially be permitted from now on. Schweigen reflects upon this: "The word is e a $t$, and to dissolve the word is to dilute the transubstantiated metaphor of physical nourishment." [16] Shortly afterwards there is a skip of thought: Schweigen tells about an acquaintance of his who he read about in the paper that morning. The guy had been shot dead. He had been a family father and a computer programmer. Although Schweigen had not known him too well, he knew that he had belonged to the new dynamic, successful generation of the sixties: the Liberal Academics, a generation that were well-off due to their ambition and diligence. The homicide will not let him go; Schweigen believes there would be some connection between the news of the murder and the conversation with the priest the night before. "I do not understand the connection (...), though there seems to be one." [17] At this point another skip of thought sets in: he thinks about his thought, trying to make sense of it, and puts materiality both in the shape of the wafer and of the bullet that hit his acquaintance in opposition to immateriality both in the shape of peaceful silence and of a tremendous amount of hatred. "I perceive in the two incidents a common element of nourishment, of eating transfigured by a strange interruption (...)." [18] He seemingly puts both positions together, tying them to the cycle of life, in their contrariety somehow belonging to one another. In the intangible of the Eucharist the act of taking the wafer materializes, and in the intangible hatred of a madman the bullet eliminating the life of a human being materializes. "About the murder I feel certain, (...) that his offense was blameless, something for which he could not have felt guilt or shame." [19] Here Schweigen's urge of reflection emerges in the shape of posing a question of guilt, exculpating his acquaintance, right or wrong suspended. The impression is, Schweigen places great strain on himself.

Shortly afterwards he gets back to the priest; he describes him as an unbiased young man who plays a twelve-string guitar, smokes menthol cigarettes, and seemingly has no problem sitting among protestants and infidels, “(..$)-$ like my late computer friend, a man of the future." [20] His words seem to carry an overtone of admiration; some for his friend, some for the priest who, pretty laid-back, seems to leave any convention behind. He will not just play the guitar but play the twelve-string, the epitome of guitar of worldly music from the mid-west. Also, he will smoke menthol cigarettes as an additional marker of individualism. Those observations seem to unsettle Schweigen; he does not seem to know what to make of them, at any rate he has an idea that times will change. His own role in the near future remains concealed to the reader as well as to Schweigen himself. At that point in the story there is a skip of time toward the present: Schweigen describes the music school which is located in the basement of a baptist church building. Here he is, waiting for his daughter, feeling the beauty and the timelessness of music. He watches young girls running around happily, being picked up by their mothers. It seems an oasis in a rat-race world. Schweigen remembers trying to learn an instrument, with not too much of a success. But he loves music: "(...) that unique language which freights each note with a double meaning of position and duration (...)." [21] $\mathrm{He}$ metaphorically relates tone pitch to duration; two components that only in their interoperation build a convincing unity. They are mutually dependent; wholeness only comes from indispensable parts. Greiner sums up, "Art, religion, and human effort merge in his description of the various lesson sounds he loves: 'hints of another world, a world where angels fumble, pause and begin again'." [22] Schweigen moves from vision toward emotion, from emotion toward vision. „Vision, timidly, becomes percussion, percussion becomes music, music becomes emotion, emotion becomes - vision. [23] "The parallel between the murdered scientist's domain of arcane numbers and the notation for a musical score is significant. Each language, music and computer, seems at first improbably opaque and complex, just like theology, but all result in the unity of vision," Greiner states to the point, [24] while Updike himself, in a rare public performance, speaks of the story of " $(\ldots)$ assembled of disparate bits, mixing deep past and present (...)." [25] Yet, what seems disparate at first might be germane to the theme and be coherent in the long run, given the writer, or the artist in general, is to attain to what Eudora Welty calls a "vision." [26] This exactly is the process that Schweigen the writer struggles with and that Updike the author provides readers with.

Schweigen admires his eight-year-old daughter, putting his hopes in her: "(...) she is eager and hopeful." [27] He sees himself detached from the events in his surroundings, he 
wants to leave the future to his daughter, yet he is not sure at all what the future will look like. Afterwards Schweigen speaks of his wife. Like himself, she consults a psychiatrist. The reason, he admits, is he cheats on her. "I do not understand the connection, but there seems to be one." [28] Again, there is that sentence of thoughtfulness, that conflict making him search for explanations. A then following skip to the past leads to a novel that Schweigen never finished writing. Through a few sentences only he gives insight into the story whose protagonist would have been a computer programmer. The story would have put him in relation to his surroundings, " $(. .$.$) - I conceived of him as being too fine,$ translucent and scrupulous to live in our coarse age." [29] It should have confronted him with the problems of everyday life. Some artificial star named Echo should have brought a science fiction component to the otherwise rather romantic storyline, "(...) the plot was to develop more or less downhill, into a case of love, guilt and nervous breakdown, with physiological complications (...) that would kill the hero as quietly as a mistake is erased from a blackboard." [30] In his mind the novel's plot has put on gestalt, yet there is not much to learn about any motifs. It rather seems as if the unconscious processes of condensation and displacement which follow the patterns of metaphor and metonymy [31] apply not only to reality but to thought, or vision, itself: a killed man becomes an erased hero, an erased hero brings about a story never finished. The metonymy carries postmodernist appeal.

What is obvious is the analogy of the protagonist of Schweigen's novel to Schweigen himself. On both of their minds the conflicts of life seem to prey. This eventually becomes apparent through the topic that he refers to next. "My psychiatrist wonders why I need to humiliate myself. It is the habit, I suppose, of confession." [32] Here Schweigen frankly speaks his mind about his tendency to humiliate himself, blame himself. He continues about his youth, about confessing, about the services when he grazed the wafer with his teeth. A feeling of doing something forbidden would begin to manifest in him and persist to the present day.

Then Schweigen gets back to the starting point: "I am neither musical nor religious. (...) My friends are like me. We are all pilgrims, faltering toward divorce" [33] Greiner sums up, "Alfred finally understands the connection between these abstract ideas and his dissolving marriage. Just as vision leads to percussion, music, emotion, and back to vision, so perhaps love leads to marriage, dissension, lawyers, divorce, and back to love." [34] Schweigen recalls the night he was sitting with the priest when his wife entered the room coming from her lawyer. After first stepping back she eventually joined them. Here Schweigen's cycle is being closed. Greiner, again, "Like the children in the music school, she fumbles, pauses, and begins again. Her courage is a grace note to Alfred's tale, providing him with his coda: 'The world is the host; it must be chewed.' Each person confronts life as he will." [35]

In the story, Updike shows the despair and the restlessness of an aging writer; the perspective momentum from which he has Schweigen speak is that of a snapshot, with an innerdirected eye typical of Updike [36]. Schweigen remains in a steady observer position, hardly being in the process of the events. Rather the middle class conflict topos of marriage, divorce, dissatisfaction is in focus - which is the scope of real life problems of human existence like loneliness, isolation, aging, and morality [37] - as is often in Updike's works.

“'Don't you love your wife?' an old girlfriend asks her would-be seducer in an early Updike story (...). 'Incredibly much', he answers honestly, and kisses the girlfriend's neck. '(...) Aren't you happy?' His baffled response (...) crystallizes the discontent that perplexes and ambiguously nourishes all the groping adulterers in Updike's fiction: 'I am, I am - but happiness isn't everything.'" [38] The ambivalence in this dialog might as well be Schweigen's; it could have been his and his lover's dialog. But only in the music school, and with that in his daughter, he will find youth and freshness. "The school itself is a metaphor for life where Schweigen ponders the harmonies of the universe while sitting in the basement of a church, only to realize that experience leads not to visions of universal order but to a requirement of knowing the self. The story, in a phrase, celebrates active participation in the world. Just as the communion wafer should no longer melt passively but must be chewed, so the complexities of living must be met." [39] So, not the topos of transubstantiation is so much in focus but the human existential issue of immateriality and materiality when looked at through the concept of the phenomenology of corporeity. [40] Bodily aspects seem to be represented in the materialization of future in Schweigen's daughter, or in wholeness through sound becoming music. Actually, Schweigen's statement of being neither musical nor religious hints at such bodily aspects in all their subjectively experienced ambivalence.

The harmony of the music school is the vacuum in which Updike has Schweigen retreat to. "My name is Alfred Schweigen and I exist in time", is what Updike has him start with. The telling name recalls Hemingway's juvenile protagonist Nick Adams who is searching for realization or, clarity of mind, in a questionable world. [41] Perhaps Updike's protagonist would prefer to be silent since after having reached insight he does not feel like telling about his private issues. Anyway, he does, maybe as some kind of selftherapy. This probably is a highly ambivalent conflict for him. The seemingly mysterious idiom, 'exist in time', might not only announce the skips of time he goes through in the process yet have him come back to the present again and again but might ironically be seen as Schweigen's struggle with keeping with the times.

After all, subjective experiencing of time is highly individual. It may vary considerably in pace and in gestalt. Viewed in terms of the life philosophy of Bergson, [42] phenomena of time are accessible foremost via intuition. This is because human experiencing of time eludes natural science; human consciousness cannot be aware of anything that is not already past. Past events are preserved and 
overcome at the same time; so individual occurrence and history are unique and irretrievable. With that, life is a reality that is experienced in human consciousness, and subjective experiencing of time is the inmost motion of life, always having present the past. Schweigen finds himself entangled in past and present. His skips of thought, together with his pensive, if not subdued mood, show him struggling with nothing less than reality proper. Still does he neither seem to accept it to the fullest, nor is he in opposition to it. He is just about stating intuitively what passes his mind.

Moreover, music, as Schweigen knows, is basically made of the interoperation of position and duration of notes, and meaning is most likely derived from melody and harmony. Some aspects of time are especially featured in the musical concept of rhythm, and there are also aspects of meaning of rhythm conceptualized reaching back to prenatal experiencing. [43] Music, seen as a phenomenon combined of mathematics and emotion, again, balks at a strictly physical concept of time - as in Bergson. Furthermore, from a phenomenological point of view learning is a process of insight, a pursuit of gestalt. An incomplete gestalt of perception needs to be completed and be put into some totality; liveliness here is defined through realizing of good gestalt. [44] This is a difficult process that might be realized in an attempt through music. So again, music becomes vision.

Updike himself sums up, "Silence and music both take place in time; in fact silence, in the form of rests, is part of music, as well as the background of it. So it was on my mind that music flows in time and lives do too. What the artist hopes to do is to freeze time by writing something that will last, and to fix a passing moment with phraseology that will make it memorable and eternal, or what we think is eternal, but, of course, is not eternal but a somewhat lasting life in print." [45]

\section{Some Parallels in Updike's Short Stories}

"Our lives submit to archeology." [46] This is the first sentence of the short story, "Harv is Ploughing Now", which is the companion piece to "The Music School." The thematic kinship is obvious; again, it is about guilt, religion, and the concept of time. Above all, there are structural parallels to be found. "The first sentence of each tale illustrates the preoccupation with time (...)." [47] Moreover, while Alfred Schweigen is in marital trouble, the narrator in "Harv is Ploughing Now" got divorced, "but Updike suggests that each narrator is a variation of the same suffering man (...)." [48] Some proposition emerges when the narrator recalls different names for petroleum for lamps in contrast to that which is for ovens: "(...) so there are essential distinctions as well as existential ones. What is bread in the oven becomes Christ in the mouth." [49] With this very Schweigenresembling statement it becomes clear that "(...) the paradox that material distinctions between physical and spiritual worlds reflect metaphorical similarities confronts both narrators (...)." [50] Moreover, the coda from "The Music School" that closes and begins Schweigen's cycle of thought might fit "Harv is Ploughing Now" as well: the finishing thoughts form the title, the title concludes and at the same time begins the cycle anew.

In another story from the collection there are more parallels to be found. "In Football Season", which was first published in Olinger Stories in 1964, is a reminiscence of times passed, of school, of adolescence, and of small town life. The attitude the narrator is in, again, resembles Schweigen's, yet nostalgia here outweighs Schweigen's resignation. Greiner's assessment is, "'In Football Season' is his [Updike's] bow to the rural world of relative innocence before focusing on the suburban experience of increasing defeat." [51] It is in the very first sentences; they exude the warmth that Schweigen seems to have lost and that the music school will bring back to him for a short time only. Both stories are founded on dialogs of the narrator with himself, and the finishing thoughts recall the courses of thought which are at the center of the stories. Schweigen envisions his daughter, “(...) her smile, biting her lower lip, pierces my heart, and I die (I think I am dying) at her feet." [52] This concluding thought in "The Music School" also recalls Schweigen's acquaintance who dies being hit by a bullet in front of his children. So Schweigen reflects the opposition of materiality and immateriality which in his view do have mutual dependencies. "In Football Season" concludes the transience of youth, "(...) from the innocent waywardness of youth to the inevitable loss of grace (...)", [53] a fact that Schweigen already seems to have realized. Yet, loss of youth is not a precondition for loss of grace, as suggested in the short story "A\&P" from the 1962 collection Pigeon Feathers, [54] in which the young protagonist puts himself out with little avail. Here it is not age that instigates loss of grace, instead it is an existential issue. [55]

\section{Conclusion}

Kostelanetz sums up the approach in short stories of the sixties, "(...) in these works the narrative is more discontinuous and the chronology even more distorted (...). The story sometimes gives the impression that it could go on forever (...)." [56] Yet, even static episodes like in Updike carry dynamics, which might be owing to the fact that style matters. [57] Issues like time, music, body, transience add up to real-world issues that when put in relation to immateriality and materiality gain momentum and move the story ahead even when protagonists sometimes feel like groping in the dark. Updike's stories illuminate short cutouts, yet they show the circumstances of life rather in an in-depth fashion than in a pan of highlights. [58] Though they are snapshots they hardly go off on a tangent but form, in a pars-pro-toto fashion, a reflection of existential issues conveyed by thoughtful impressions. In a way, the existential dimension is in the process of reflection itself. In "The Music School", in order to gain insight into being, Updike's narrator draws on 
everyday dealings of reality, only to come to a process of conclusion about life itself. Such a process, of course, will not come at no cost. Yet, it is a basic need in order to develop further personally and artistically since, as Brooks and Warren put it, “(...) what our imagination craves is not a flight from actuality, but an illumination of it, a new vision of it." [59]

\section{References}

[1] Kostelanetz R (1972). Notes on the American Short Story today. In: Bungert H (ed.). Die amerikanische Short Story. Theorie und Entwicklung. Darmstadt, p. 355.

[2] Goeller KH, Hoffmann G (1972). Die amerikanische Kurzgeschichte. Duesseldorf, p. 15-16.

[3] loc. cit.

[4] loc. cit.

[5] Goeller, Hoffmann, p. 18-20.

[6] Goeller, Hoffmann, p. 20.

[7] The changes in contents brought about changes in forms that would more often than not turn literary conventions upside down; see Klinkowitz J (1980). The American 1960's: Imaginative Acts in a Decade of Change. Ames IA: Iowa State University Press, and Egloff G (2014). Treating the Fiction of Forms: Metafiction in John Barth. Intl J Literature and Arts, 2, 1, pp. $1-5$.

[8] For the development of the short story also see Current-Garcia E, Patrick WR (1979). What is the Short Story? Case Studies in the Development of a Literary Form. Rev. ed. Glenview IL: Scott, Foresman \& Co.

[9] Greiner DJ (1981). The other John Updike. Athens OH, p. 135.

[10] cp. Ahrends G (1980). Die amerikanische Kurzgeschichte. Theorie und Entwicklung. Stuttgart, p. 201.

[11] Kostelanetz, p. 358.

[12] Kostelanetz, p. 364.

[13] Thorburn D (1979). Alive in a Place and Time. In: Thorburn D, Eiland H (eds.). John Updike. A Collection of Critical Essays. Englewood Cliffs NJ, p. 2.

[14] Modernism in the sixties, of course, is a modernism that is mostly either conflated with (psychological) realism, or, at least partially, on the brink of post-modernism (the realistic type quite often being better receptible to readers, though); $\mathrm{cp}$. Kress D, Egloff G (2007). Bilder der 1950er bei Salinger, Roth und Updike. Gesellschaft und Zeitgeschichte in der USNachkriegsliteratur. Marburg.

[15] Ahrends, p. 201.

[16] Updike J (1966/1967). The Music School. Short Stories. First edition 1966. New York: Fawcett World Library, 1967, p. 138.

[17] Updike (1966/1967), p. 139.

[18] loc. cit.
[19] Updike (1966/1967), p. 140.

[20] loc. cit.

[21] loc. cit.

[22] Greiner, p. 155.

[23] Updike (1966/1967), p. 140.

[24] Greiner, p. 155.

[25] Schiff JA (ed.) (2007). Updike in Cincinnati. A Literary Performance. Athens OH, p. 63.

[26] cp. Brooks C, Warren RP (1979). Fiction and Human Experience. In: Brooks C, Warren RP (eds.). Understanding Fiction. Englewood Cliffs NJ, pp. 293-296.

[27] Updike (1966/1967), p. 140.

[28] Updike (1966/1967), p. 141.

[29] loc. cit.

[30] loc. cit.

[31] cp. Meyer M (2004). English and American Literatures. Tuebingen: Francke, p. 127.

[32] Updike (1966/1967), p. 142.

[33] loc. cit.

[34] Greiner, p. 156.

[35] Greiner, p. 156-157.

[36] cp. Mazzeno LW (2013). Becoming John Updike. Critical Reception, 1958-2010. Rochester NY: Camden House, p. 20.

[37] Vaughan PH (1981). John Updike's Images of America. Reseda CA: Mojave.

[38] Thorburn, p. 3.

[39] Greiner, p. 154.

[40] cp. Merleau-Ponty M (1945/2011). Phaenomenologie der Wahrnehmung. Berlin: deGruyter.

[41] Goeller, Hoffmann, p. 21.

[42] cp. Danzer G (2011). Henri Bergson. In: Danzer G (ed.). Wer sind wir? Anthropologie im 20. Jahrhundert. Berlin/Heidelberg, pp. 17-29.

[43] Janus L (2000). Die Psychoanalyse der vorgeburtlichen Lebenszeit und der Geburt. Giessen: Psychosozial.

[44] cp. Rattner J (1995). Maurice Merleau-Ponty. In: Rattner J. Klassiker der Psychoanalyse. Weinheim: Beltz/PVU, pp. 830853.

[45] Schiff, p. 63.

[46] Updike J (1967/1970). The Music School. Short Stories. First published by Andre Deutsch in 1967. London: Penguin, 1970, p. 140 .

[47] Greiner, p. 153.

[48] loc. cit. 
[49] Updike (1967/1970), p. 140.

[50] Greiner, p. 153.

[51] Greiner, p. 134.

[52] Updike (1966/1967), p. 143.

[53] Greiner, p. 134.

[54] Updike J (1962/1979). “A\&P”. In: Brooks C, Warren RP (eds.) (1979). Understanding Fiction. Englewood Cliffs NJ, pp. 432-436.
[55] For more on the story see Uphaus SH (1980). John Updike. New York: Frederick Ungar.

[56] Kostelanetz, p. 362.

[57] cp. Batchelor B (2013). John Updike. A Critical Biography. Santa Barbara CA: Praeger/ABC-Clio.

[58] For an overview of critical responses to his 1960's prose see Mazzeno (2013).

[59] Brooks, Warren, pp. 293-296. 